\title{
Symbiotic Microbes from Marine Invertebrates: Driving a New Era of Natural Product Drug Discovery
}

\author{
Alix Blockley ${ }^{1, *}$, David R. Elliott ${ }^{1}$ (D), Adam P. Roberts ${ }^{2,3}$ and Michael Sweet ${ }^{1}$ \\ 1 Aquatic Research Facility, Environmental Sustainability Research Centre, University of Derby, \\ Derby DE22 1GB, UK; D.R.Elliott@derby.ac.uk (D.R.E.); M.Sweet@derby.ac.uk (M.S.) \\ 2 Department of Parasitology, Liverpool School of Tropical Medicine, Pembroke Place, Liverpool L3 5QA, UK; \\ Adam.Roberts@lstmed.ac.uk \\ 3 Research Centre for Drugs and Diagnostics, Liverpool School of Tropical Medicine, Pembroke Place, \\ Liverpool L3 5QA, UK \\ * Correspondence: A.Blockley@derby.ac.uk
}

Received: 15 September 2017; Accepted: 23 October 2017; Published: 28 October 2017

\begin{abstract}
Invertebrates account for more than $89 \%$ of all extant organisms in the marine environment, represented by over 174,600 species (recorded to date). Such diversity is mirrored in (or more likely increased by) the microbial symbionts associated with this group and in the marine natural products (or MNPs) that they produce. Since the early 1950s over 20,000 MNPs have been discovered, including compounds produced by symbiotic bacteria, and the chemical diversity of compounds produced from marine sources has led to them being referred to as "blue gold" in the search for new drugs. For example, $80 \%$ of novel antibiotics stemming from the marine environment have come from Actinomycetes, many of which can be found associated with marine sponges, and compounds with anti-tumorigenic and anti-diabetic potential have also been isolated from marine symbionts. In fact, it has been estimated that marine sources formed the basis of over $50 \%$ of FDA-approved drugs between 1981 and 2002. In this review, we explore the diversity of marine microbial symbionts by examining their use as the producers of novel pharmaceutical actives, together with a discussion of the opportunities and constraints offered by "blue gold" drug discovery.
\end{abstract}

Keywords: marine natural products; microbial symbionts; marine invertebrates; pharmaceuticals; "blue gold"

\section{Introduction}

The term symbiosis was first defined by the German surgeon Anton de Bary in 1878 as "the living together of differently named organisms" [1]. In nature, symbioses are frequently represented by a microorganism living with a host-such as an animal, plant, or another microorganism [2]. Symbiotic interactions can be parasitic, commensal, or mutualistic [3,4]; the latter being defined by de Bary as a system "in which there is a reciprocal benefit for the symbionts" [1]. These mutually beneficial living arrangements are common, and have frequently evolved to be essential to the livelihood of both partners-in the absence of their microbial symbionts, most animals and plants could not survive [2].

Due to co-evolution with their specific host, microbial symbionts express a variety of uniquely tailored biochemical traits, making them a highly productive source of secondary metabolites with well-defined architectures and medically and commercially attractive bioactivities [5]. As these compounds evolved to interact efficiently with a co-evolving biological target they are often structurally unique; indeed the Dictionary of Natural Products states that over $40 \%$ of these chemical scaffolds occupy a chemical space not represented by synthetic compounds [6]. Furthermore, they tend to be complex and with well-defined spatial orientations, and as this unique diversity is coupled with the occupation of a biologically relevant chemical space, these natural products are an excellent starting 
point for drug discovery [7]. Of the 1184 new compounds approved between the years 1981-2006 as drugs for the treatment of human diseases the majority were derived from natural products and only $30 \%$ were of synthetic origin [8]. Along with their clinical advantages, drugs derived from natural products are in high demand. In 2000 approximately half of the 20 best-selling non-protein drugs were related to natural products [9] and the demand for such products is increasing; for example, it has been estimated that by 2020 around $\$ 115$ billion will be spent globally on herbal supplements alone [10], and in 2014, consumers spent around $\$ 6.4$ billion on herbal supplements in the United States-a $6.8 \%$ increase over 2013 and the 11th consecutive year of increased market growth [11]. The term "natural product" is clearly embraced by consumers [12].

Arguably one of the most productive branches of natural pharmaceutical development is that of the marine natural products (MNPs), known as "blue gold" drug discovery, the development of novel actives from the marine environment [7]. A comparative analysis by Kong et al. in 2010 showed that MNPs have greater chemical novelty compared to their terrestrial counterparts [13], and many of these compounds have advanced to clinical trials and pharmaceutical products $[5,14,15]$. Since 1965 over 20,000 MNPs have been described [16], that have formed the basis of over 50\% of FDA-approved drugs in the period 1981-2002 [17]. In 2015 alone 1340 new MNPs have been published in 429 papers [14]; as our oceans cover $71 \%$ of the earth's surface, yet remain 95\% unknown [18], the potential for further drug discovery is immense.

At the time of writing, more than 30,607 articles focusing on MNPs have been uploaded to MarinLit, a database of MNP literature [16], many of which relate to MNPs produced by marine invertebrates, most notably marine sponges and corals [19-21]. Marine invertebrates account for over $89 \%$ of all extant marine animals, comprising of over 174,600 species [22]; this diversity is not only found between the animals themselves, but also between the symbiotic microorganisms that comprise the entire holobiont [23-29]. More than 47 bacterial phyla have been sequenced from sponges alone [30], and high throughput sequencing of the 16S rRNA gene has unveiled an incredible diversity of symbiotic bacteria within the sponge body $[31,32]$.

It is now thought that many of the MNPs with pharmacological activity that have been isolated from marine invertebrates are likely to be produced, not by the animals themselves, but rather by their symbiotic microbiota [8,33-35]; for example, $80 \%$ of antibiotics from marine sources come from Actinomyces spp., several species of which are associated with marine sponges [36-38]. Given that endosymbiotic bacteria make up to $50-60 \%$ of the dry weight of a sponge, there are certain to be many marine symbionts producing as yet undiscovered bio-active compounds [39].

This review showcases the diversity of marine invertebrate symbionts via notable examples of the pharmaceutical MNPs they produce. A brief discussion of the opportunities and constraints inherent in such drug discovery is also included.

\section{2. $\beta$-glucosidase Inhibitors: Compounds with Anti-Diabetic Potential}

In 2013 over 382 million people were estimated to be suffering from diabetes mellitus (commonly called diabetes), by 2030 this figure is estimated to rise to 500 million [40]; in 2015 diabetes was listed as number five in the top causes of death by The World Health Organisation (WHO) [41].

The increasing prevalence of diabetes, coupled with the seriousness of the disease, has resulted in an extensive search for novel anti-diabetics, some searches of which have focused within the marine biome. We refer readers to a recent review by Lauritano and Ianora [42], who focus on the recent advances in the discovery of marine organisms with such anti-diabetic properties. Targets examined in anti-diabetic drug screening include specific enzymes involved in sugar metabolism, proteins involved in the signaling of insulin responsive tissue, molecules able to protect pancreatic $\beta$ cells (in type- 1 diabetes studies), and molecules implicated in diabetic retinopathy-one of the most common and debilitating side-effects of diabetes [42]. In 2013 Pandey et al. screened 181 bacteria from marine sediment and sponges for $\beta$-glucosidase inhibitors; these compounds are likely to act on the glucosidase 
enzymes of other microorganisms, providing a competitive edge to the microbe producing them in the crowded ecological niche of the marine environment [43].

Glucosidase enzymes catalyze the cleavage of glycosidic bonds involving $\alpha$ - and $\beta$-linked glucose units, or the bonds between sugars and a non-carbohydrate aglycone moiety, and as such are involved in glucose production [43,44]. The classic $\beta$-glucosidase inhibitor, nojirimycin from Streptomyces roseochromogenes (Strain R-468) and Streptomyces lavendulae (Strain SF-425), and its derivatives are at present extensively used in the treatment of type II diabetes (Figure 1) [45-47].

The screening process in 2013 found 41 bacteria producing $\beta$-glucosidase inhibitors, of which $34 \%$ were associated with marine sponges -6 out of $41(14.6 \%)$ isolates from the sponge Sarcotragus fasciculatus and 8 out of $30(26.6 \%)$ from the sponge Aka coralliphaga produced the compounds. These corresponded to 3 and 7 different species respectively, of which 2 and 6 were identified to the species level (Table 1) [43].

Table 1. Select MNPs of pharmaceutical significance isolated from symbionts of marine invertebrates.

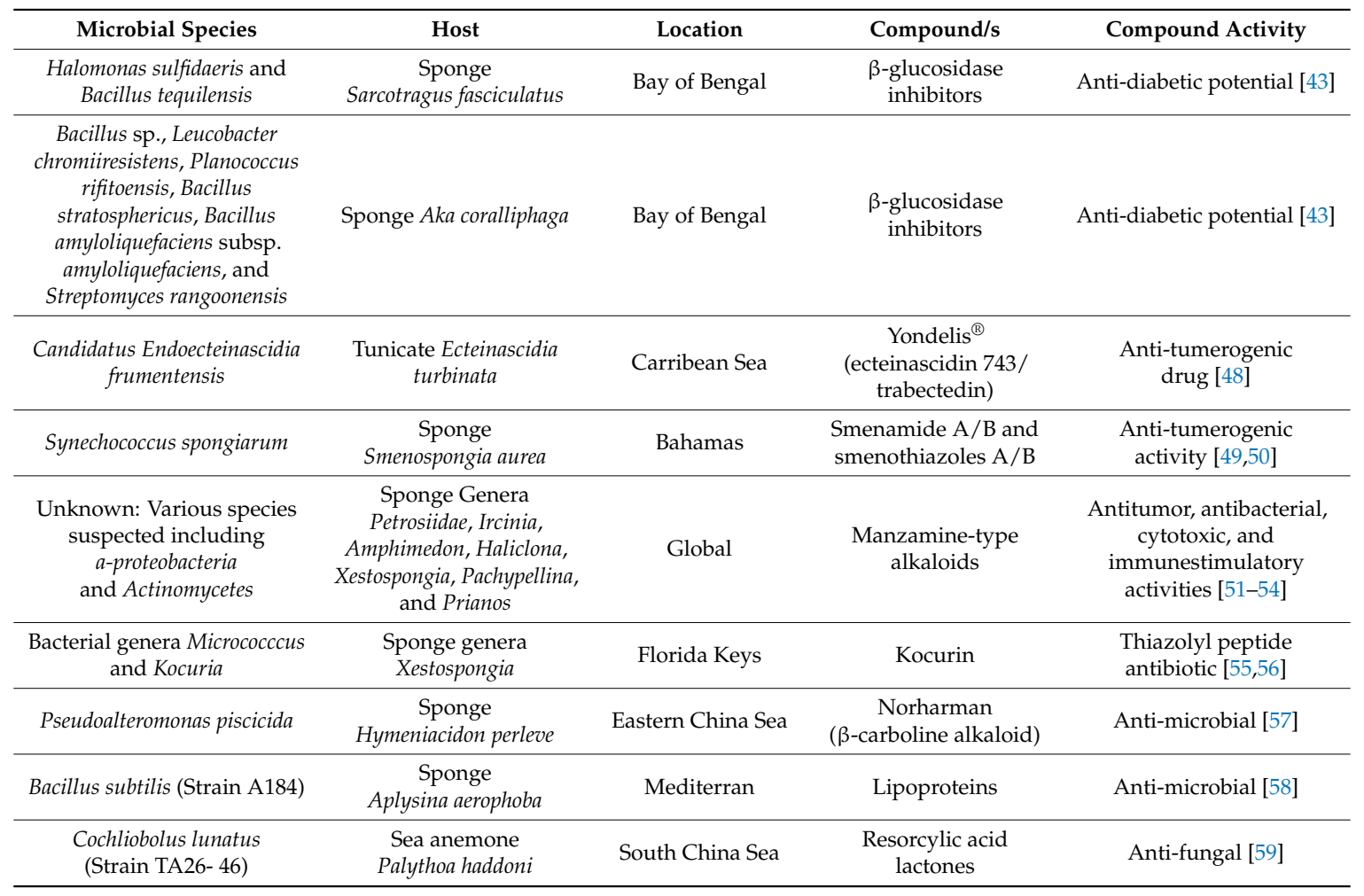

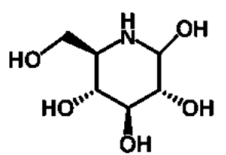

(a)

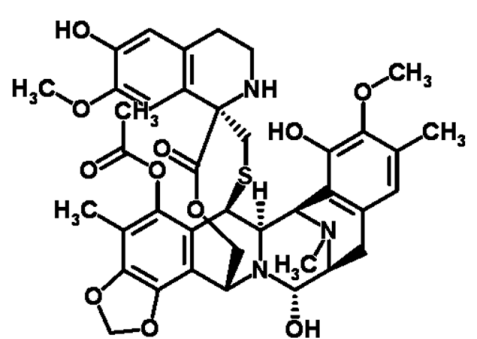

(b)

Figure 1. Cont. 


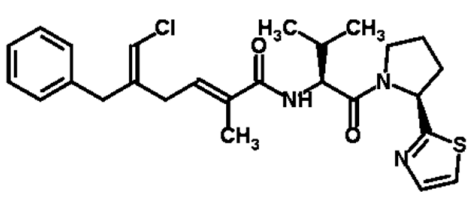

(c)

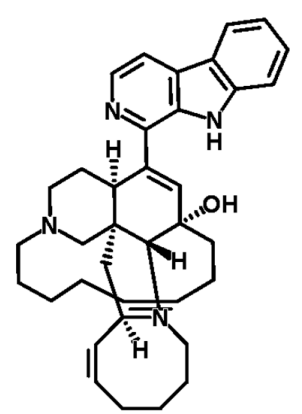

(e)

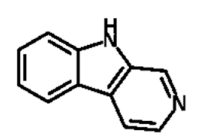

(g)<smiles></smiles>

(d)

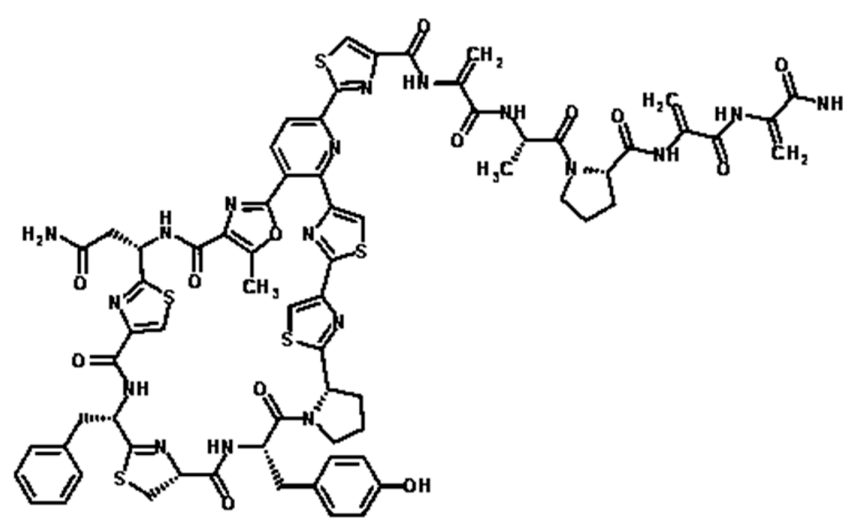

(f)

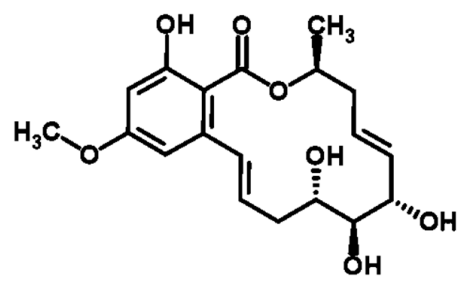

(h)

Figure 1. Structures of compounds with pharmacological activity produced by microbes: (a) nojirimycin $[47,60]$, an exemplar $\beta$-glucosidase inhibitor; (b) Yondelis ${ }^{\circledR}$ (ecteinascidin 743/trabectedin) [61-63], (c) smenothiazole A [49,64], and (d) smenothiazole B [49,65], exemplar anti-tumorigenic compounds; (e) manzamine A [66,67], an exemplar multi-functional drug; (f) kocurin [55,68], an exemplar antibiotic; (g) norharman (a $\beta$-carboline alkaloid) $[51,57,69]$, an exemplar anti-microbial compound; (h) zeaenol (a resorcylic acid lactone) [59,70], an exemplar anti-fungal compound.

\section{Yondelis ${ }^{\circledR}$, Smenamides, and Smenothiazoles: Compounds with Anti-Tumorigenic Potential}

In a US National Cancer Institute preclinical cytotoxicity screening program over 1\% of MNPs showed anti-tumor properties; this is 10 times greater than their estimate for natural products of a terrestrial origin, at only $0.1 \%$ [71]. This is potentially reflected in the number of successful anti-tumorigenic compounds isolated from marine invertebrates that have made it to market. The first of these, a synthetic analogue of a C-nucleoside from the sponge Tethya crypta, was ara-C (4-cytarabine, Alexan $\left.{ }^{\circledR}, \mathrm{Udicil}^{\circledR}\right)$, approved in 1969 it is still used today to treat acute myelocytic leukemia and non-Hodgkin's lymphoma [72-74]. Following from this initial discovery, a variety of other anti-cancer drugs from marine invertebrates have been developed. These include for example; Halaven ${ }^{\circledR}$ (eribulin), used to treat metastatic breast cancer [75] and developed from the metabolite halichondrin B produced by the sponge Halichondria okadai [76,77], and ADCETRIS ${ }^{\circledR}$ (brentuximab vedotin, SGN-35) used for the treatment of Hodgkin lymphoma and anaplastic large cell lymphoma [78], and developed via antibody chimerisation through the addition of a dipeptide linker to the potent antitubulin agent dolastatin 10 from the sea hare Dolabella auricularia $[79,80]$. 
Illustrative of the importance of symbionts to marine drug discovery, some of these anti-tumorigenic compounds are now suspected to originate from the marine invertebrates symbiotic bacteria, rather than the host itself $[8,19,34]$. For example, this is true of the anti-tumorigenic drug Yondelis ${ }^{\circledR}$ (Figrue 1), approved in 2007 for the treatment of ovarian cancer and tissue sarcomas [62]. In the 1950s the American National Cancer Institute began a comprehensive program of screening marine material for possible anti-cancer properties, as part of this program an extract from the tunicate Ecteinascidia turbinata was found to have anticancer activity. Eventually, the structure of one of the active compounds within this extract, ecteinascidin 743 (ET-743), was determined by KL Rinehart [81]. A synthetic synthesis pathway was developed [82], leading to the drug, trabectedin, this active compound was then used successfully in clinical trials and marketed as Yondelis ${ }^{\circledR}[62,63]$. Interestingly, ET-743 has since been shown, not to derive from E. turbinata itself, but rather from one of its symbionts, a $\gamma$-proteobacterium Candidatus Endoecteinascidia frumentensis. Firstly, the real origin of the active compound was implied indirectly, by observation that $E$. frumentensis was the most prevalent member from the tunicate microbial consortium at all collection sites in the Mediterranean and Caribbean seas $[83,84]$. However, more recently, Rath et al. employed novel techniques involving Meta-Omic characterization of the microbial consortium associated with E. turbinata and revealed 25 genes that comprise the core of the ET-743 biosynthetic pathway, and resulting sequence analysis strongly suggested that E. frumentensis is in fact the producer of ET-743 (Table 1) [48].

Similarly, the compounds smenamide A and B, which show potent cytotoxic activity at nanomolar levels on lung cancer Calu- 1 cells, are likely to originate from a symbiont of another marine invertebrate. These compounds were isolated as a result of a detailed study into the secondary metabolites contained within the lipophilic extract of the sponge Smenospongia aurea. Samples were collected along the coast of Little Inagua (Bahamas Islands) as part of a broad screening program conducted by the NeaNat research group at the Università degli Studi di Napoli Federico II in Naples, Italy. This in depth examination led to the elucidation of structures of the two smenamides, and these smenamides appeared to be the products of cyanobacterial metabolism. Indeed further 16S rRNA metagenomic analysis detected Synechococcus spongiarum as the only cyanobacterium present in S. aurea and thus the likely producer of these anti-tumorigenic compounds [50]. Further study on the same sponge species revealed two further anti-tumorigenic compounds, this time with selectivity for ovarian cancer cells. These compounds, the smenothiazoles A and B (Figure 1), also contained structural motifs that are present in cyanobacterial metabolites, and as such likely also originate from S. spongiarum (Table 1) [49].

\section{Manzamine, Kocurin, Norharman, Lipopeptides, and Lactones: Compounds with Anti-Pathogenic Potential}

Marine microorganisms live in highly competitive environments, selecting for the evolution of various chemical protection strategies, such as the production of anti-microbial, anti-fungal, or anti-viral secondary metabolites [85]. Those microbes which have formed symbiotic relationships with a marine invertebrate, like a sponge or coral, have often developed further secondary metabolites, which also protect their hosts from pathogens [86,87]. This combination of self and host protection has selected for a huge range of secondary metabolites isolated from marine symbionts that are reported to have anti-microbial or anti-pathogenic properties $[8,19]$.

Manzamines, produced by actinomycete Micromonospora species for example, are associated with several sponge genera, and have significant potential as anti-pathogenic compounds as they have been shown to have in vitro and in vivo activity against the malaria parasite Plasmodium berghei [51,66,88-92]. Furthermore, they are also active against Mycobacterium tuberculosis (now responsible for more deaths worldwide than HIV) and Leishmania, as well as having insecticidal properties [51,66,88-92]. The importance of manazamines was recognized as early as 1986 when Sakai and co-workers first reported manzamine A from the Okinawan sponge of the genus Haliclona (Figure 1) [66]. Since this first report, 40 more manzamine-type alkaloids have been reported from several different sponge genera (Table 1) [51-54]. 
Also from sponge-associated actinomycete bacteria the molecule kocurin (Figure 1), a new member of the thiazolyl peptide family of antibiotics, has been isolated from strains in the family Microccocaceae [19]. In their 2013 study Palomo et al. isolated 44 Microccocaceae strains from sponges collected in the Florida Keys, and off the coast of Fort Lauderdale and Maryland in the USA. Based on $16 \mathrm{~S}$ rRNA gene sequences, 15 strains were found to belong to the genera Micrococccus and 29 to the genera Kocuria. All Micrococcus strains were found to be of the same species, M. yunnanensis, whereas Kocuria strains belonged to 7 different species: K. flava, K. marina, K. palustris, K. rhizophila, K. rosea, $K$. sediminis and $K$. turfanensis $[55,56]$. Following identification, these strains were screened for the presence of secondary metabolite genes, then grown in nutritional arrays; finally, strains were analyzed for the production of antibacterial and antifungal activities in whole-cell agar-based growth inhibition assays. These assays targetted clinically relevant strains of Bacillus subtilis (MB964), and the pathogens; methicillin-resistant Staphylococcus aureus (MRSA) (MB5393), Acinetobacter baumannii (MB5973) and the yeast Candida albicans (MY1055). Three isolates were shown to produce a new anti-MRSA bioactive compound, Kocuria marina F-276,310, Kocuria palustris F-276,345, and Micrococcus yunnanensis F-256,446, and this compound was identified as kocurin (Table 1) [55]. In the same study, the group also confirmed that two related strains of Microccocaceae, corresponding to the Arthrobacter strains; R-7513 and R-7914, that they had previously isolated from Antarctic microbial mats also produced kocurin $[55,56,93]$.

The Phylum Proteobacteria is the second largest group producing bioactive metabolites associated with sponges after the Actinobacteria (discussed above) [19]. For example, norharman (a $\beta$-carboline alkaloid) is an anti-microbial metabolite (Figure 1), isolated from strains of the bacteria Pseudoalteromonas piscicida which have been shown to be associated with the sponge Hymeniacidon perleve [57]. Out of 29 strains isolated during a study by Zheng et al. in 2005, eight strains inhibited the growth of various other pathogenic microorganisms. P. piscicida strain NJ6-3-1 showed a wide antimicrobial spectrum, being active against Bacillus subtilis (CMCC 63003), Staphylococcus aureus (CMCC 26001), Escherichia coli (CMCC 44102), and Agrobacterium tumefaciens (AS 1.1416). Furthermore, NJ6-3-1 also displayed antifungal activity against the yeast Saccharomyces cerevisiae ACCC 2.1882. The major antimicrobial metabolite from this strain was identified as norharman, and was actually previously isolated from Indonesian sponges by Rao et al. two years earlier (Table 1) [51,57].

Bacteria from other phyla, such as Firmicutes for example, have also been shown to produce anti-pathogenic compounds, especially strains of Bacillus [19]. The Mediterranean sponge Aplysina aerophoba contains brominated metabolites with strong antimicrobial activity [94], thus in 2003 Pabel et al. reasoned that as symbiotic bacteria residing in $A$. aerophoba must be resistant to these bioactive metabolites, they may be capable of producing similar antimicrobial compounds themselves. They discovered 5 Bacillus isolates with pronounced antifungal and antimicrobial activities. One particular strain of Bacillus subtilis (A184), was shown to produce anti-microbial lipoproteins namely iturins, fengycins and surfactins [58]. This strain had antimicrobial activity against Staphylococcus aureus, Escherichia coli, Vibrio species SB1 (a marine isolate), Clavibacter michiganensis, Bacillus megaterium, Proteus vulgaris and Agrobacterium tumefaciens, and had antifungal activity against the mold Paecilomyces variotii and the yeast Candida albicans. Of particular note, was the activity of strain A184 against the multi-drug resistant Staphylococcus aureus (Strain A134-is resistant to ciprofloxacin, clindamycin, erythromycin, gentamicin, oxacillin, penicillin G) and the multi-drug resistant Staphylococcus epidermidis (Strain RP62A-which is resistant to clindamycin, erythromycin, gentamicin, oxacillin, penicillin $\mathrm{G}$, and trimethoprim) (Table 1) [58].

In addition to bacteria, anti-pathogenic compounds are also made by symbiotic fungi associated with various marine invertebrates [8]. For example, Cochliobolus lunatus (strain TA26- 46), isolated by Liu et al. in 2014 from the sea anemone Palythoa haddoni was found to produce resorcylic acid lactones, compounds that had previously been shown to have activity against pathogenic fungi [59]. Of eleven compounds, an isolated one, zeaenol (Figure 1), exhibited excellent fungicidal activity against the crop-pathogenic fungi Plasmopara viticola and Phytophthora infestans in a whole-plant assay (Table 1) [59]. 


\section{Constraints and Future Prospects}

This review highlights but a few of the compounds produced by microbial symbionts that have potential as pharmaceuticals $[8,73,95,96]$. For example, we draw readers to the recent excellent review by Zhang et al. which describes in detail over 107 cytotoxic agents which have been discovered from 1955 to 2016 that are metabolized by marine sponge-derived symbionts alone [95] (including terpenes, alkaloids, peptides, aromatics, lactones, and steroids, amongst others). Several other recent detailed reviews are also available which provide information on the many compounds discovered from marine invertebrates, including cytotoxic, anti-microbial, anti-protozoal, anti-leishmanial, anti-trypanosomal and anti-inflammatory compounds, compounds which may actually originate from the host-associated microbes and not the invertebrates themselves [8,19,20,48,97-106].

In addition, the screening of such symbiotic microbes from marine invertebrates is only beginning to scratch the surface with regard to finding cures and treatments for many diseases. The screening process carried out by Pandey et al. for $\beta$-glucosidase inhibitors as anti-diabetics examined only two sponge species, with over 9000 described members of Porifera, the possibilities are staggering [43]. Indeed, other studies are also starting to show other anti-diabetic compounds from both sponges and even corals [42].

It should be noted here, that despite the clear benefits to MNP discovery, there are certain constraints faced by researchers in the hunt for "blue gold"; the principle one being that many symbionts are currently unculturable away from their respective hosts. In fact it is estimated that as many as $99 \%$ are considered "unculturable" [107], thus making the screening and mass-production of any pharmaceuticals they produce very difficult using common culturing methods [85]. One seemingly simple solution to this problem is to culture the host organism along with the symbiont, in a manner that maximises secondary metabolite production by the microbe $[21,108,109]$. However, this adds an extra level of complexity to the culturing procedure, having to accommodate the needs of an entire complex holobiont. The conditions used would have to mimic the exact natural conditions of the host marine invertebrate to ensure it was in a state that promoted growth of the desired symbiont, as it has been shown that the microbial composition of certain marine invertebrates, like corals for example can vary significantly under ex-situ culturing conditions [110,111]. That said, recent advances in the design of new culture media, the development of nature-mimicking culture systems, the optimization of growth conditions in bioreactors, the development of efficient automated harvesting protocols for organisms with biotechnological potential, and the invention of different ways of co-cultivation and mixed culturing $[8,112]$ appear to be addressing these issues, at least to some degree.

Alternatively, the advances occurring at a rapid rate in the fields of bioinformatics and molecular biology may offer the potential to clone a gene of interest into a heterologous system, then express the desired product in an easier-to-culture host (effectively removing the issues described above). Various antimicrobial MNPs have indeed been discovered by using the approach of cloning metagenomic DNA (the entire DNA from an environmental niche) into such a heterologous host, a process known as functional metagenomics (reviewed in Trindade et al. and references therein) [113]. Although, such heterologous hosts may in turn prove incompatible in terms of their expression of heterologous DNA, and toxicity of any expressed products [8] the potential of functional metagenomics in gaining access to a vast range of products produced by as yet uncultivable microbes remains attractive to researchers.

\section{Conclusions}

To conclude, given the sheer number of marine invertebrates present in the ocean, and the even greater number of associated microbes on and within each host, it is without doubt that there are many more MNPs to be discovered-offering significant opportunity to treat complex diseases that are increasing in prevalence, such as multi-drug resistant infections, neglected tropical diseases, cancer, and diabetes. Current obstacles to turning these actives into useable, cost-effective drugs are being overcome due to intensive efforts into optimising culturing techniques and chemical synthesis, this 
work, coupled with advances in metabolomics and bio-informatics to identify compound-producing species-means that symbionts are providing a promising future for "blue gold" drug discovery.

Acknowledgments: Funding for Alix Blockley, David Elliott, and Michael Sweet was received from the Environmental Sustainability Research Centre at the University of Derby.

Author Contributions: Authors contributed equally to the manuscript.

Conflicts of Interest: The authors declare no conflict of interest.

\section{References}

1. Oulhen, N.; Schulz, B.J.; Carrier, T.J. English translation of Heinrich Anton de Bary's 1878 speech, “Die Erscheinung der Symbiose" (“De la symbiose”). Symbiosis 2016, 69, 131-139. [CrossRef]

2. Staley, J.T.; Castenholz, R.W.; Colwell, R.R.; Holt, J.G.; Kane, M.D.; Pace, N.R.; Salyers, A.A.; Tiedje, J.M. The Microbial World: Foundation of the Biosphere; Colloquia Report; American Academy of Microbiology: Washington, DC, USA, 1997.

3. Egerton, F.N. History of ecological sciences, part 52: Symbiosis studies. Bull. Ecol. Soc. Am. 2015, 96, 80-139. [CrossRef]

4. Paracer, S.; Ahmadjian, V. Symbiosis: An introduction to biological associations; Oxford University Press: Oxford, UK, 2000; ISBN 0195118073.

5. Zhang, X.; Wei, W.; Tan, R. Symbionts, a promising source of bioactive natural products. Sci. China Chem. 2015, 58, 1097-1109. [CrossRef]

6. Henkel, T.; Brunne, R.M.; Müller, H.; Reichel, F. Statistical investigation into the structural complementarity of natural products and synthetic compounds. Angew. Chem. Int. Ed. 1999, 38, 643-647. [CrossRef]

7. Montaser, R.; Luesch, H. Marine natural products: A new wave of drugs? Future Med. Chem. 2011, 3, 1475-1489. [CrossRef] [PubMed]

8. Romano, G.; Costantini, M.; Sansone, C.; Lauritano, C.; Ruocco, N.; Ianora, A. Marine microorganisms as a promising and sustainable source of bioactive molecules. Mar. Environ. Res. 2017, 128, 58-69. [CrossRef] [PubMed]

9. Harvey, A. Strategies for discovering drugs from previously unexplored natural products. Drug Discov. Today 2000, 5, 294-300. [CrossRef]

10. Global Industry Analysts Inc. The Global Herbal Supplements and Remedies Market: Trends, Drivers and Projections, February 2015. Available online: www.strategyr.com/MarketResearch/Herbal_Supplements_ and_Remedies_Market_Trends.asp (accessed on 17 August 2017).

11. Smith, T.; Lynch, M.E.; Johnson, J.; Kawa, K.; Bauman, H.; Blumenthal, M. Herbal dietary supplement sales in US increase $6.8 \%$ in 2014. HerbalGram 2015, 107, 52-59.

12. Gabay, M.; Smith, J.A.; Chavez, M.L.; Goldwire, M.; Walker, S.; Coon, S.A.; Gosser, R.; Hume, A.L.; Musselman, M.; Phillips, J.; et al. White paper on natural products. Pharmacotherapy 2017, 37, 1-15. [CrossRef] [PubMed]

13. Kong, D.X.; Jiang, Y.Y.; Zhang, H.Y. Marine natural products as sources of novel scaffolds: Achievement and concern. Drug Discov. Today 2010, 15, 884-886. [CrossRef] [PubMed]

14. Blunt, J.W.; Copp, B.R.; Keyzers, R.A.; Munro, M.H.G.; Prinsep, M.R. Marine natural products. Nat. Prod. Rep. 2017, 34, 235-294. [CrossRef] [PubMed]

15. Bauer, A.; Brönstrup, M. Industrial natural product chemistry for drug discovery and development. Nat. Prod. Rep. 2014, 31, 35-60. [CrossRef] [PubMed]

16. MarinLit: A Databse of the Marine Natural Products Literature. Available online: http://pubs.rsc.org/ marinlit/ (accessed on 26 May 2017).

17. Gerwick, W.H.; Moore, B.S. Lessons from the past and charting the future of marine natural products drug discovery and chemical biology. Chem. Biol. 2012, 19, 85-98. [CrossRef] [PubMed]

18. National Ocean Service; National Oceanic and Atmospheric Administration; U.S. Department of Commerce. Ocean Facts: How Much of the Ocean Have We Explored? Available online: http:/ / oceanservice.noaa.gov / facts/exploration.html (accessed on 26 May 2017).

19. Bibi, F.; Faheem, M.; Azhar, E.I.; Yasir, M.; Alvi, S.A.; Kamal, M.A.; Ullah, I.; Nasser, M.I. Bacteria from marine sponges: A source of new drugs. Curr. Drug Metab. 2016, 17, 1-6. [CrossRef] [PubMed] 
20. Andersen, R.J. Sponging off nature for new drug leads. Biochem. Pharmacol. 2017, 139, 3-14. [CrossRef] [PubMed]

21. Leal, M.C.; Calado, R.; Sheridan, C.; Alimonti, A.; Osinga, R. Coral aquaculture to support drug discovery. Trends Biotechnol. 2013, 31, 555-561. [CrossRef] [PubMed]

22. Horton, T.; Kroh, A.; Bailly, N.; Boury-Esnault, N.; Brandão, S.N.; Costello, M.J.; Gofas, S.; Hernandez, F.; Mees, J.; Paulay, G.; et al. World Register of Marine Species. Available online: http:/ / marinespecies.org/ (accessed on 25 May 2017).

23. Thompson, J.R.; Rivera, H.E.; Closek, C.J.; Medina, M. Microbes in the coral holobiont: Partners through evolution, development, and ecological interactions. Front. Cell. Infect. Microbiol. 2015, 4, 1-20. [CrossRef] [PubMed]

24. Peixoto, R.S.; Rosado, P.M.; de Assis Leite, D.C.; Rosado, A.S.; Bourne, D.G. Beneficial microorganisms for corals (BMC): Proposed mechanisms for coral health and resilience. Front. Microbiol. 2017, 8, 1-16. [CrossRef] [PubMed]

25. Bourne, D.G.; Morrow, K.M.; Webster, N.S. Insights into the coral microbiome: Underpinning the health and resilience of reef ecosystems. Annu. Rev. Microbiol. 2016, 70, 317-340. [CrossRef] [PubMed]

26. Webster, N.S.; Thomas, T. Defining the sponge hologenome. mBio. 2016, 7, 1-14. [CrossRef] [PubMed]

27. Fuerst, J.A. Diversity and biotechnological potential of microorganisms associated with marine sponges. Appl. Microbiol. Biotechnol. 2014, 98, 7331-7347. [CrossRef] [PubMed]

28. Taylor, M.W.; Radax, R.; Steger, D.; Wagner, M. Sponge-associated microorganisms: Evolution, ecology, and biotechnological potential. Microbiol. Mol. Biol. Rev. 2007, 71, 295-347. [CrossRef] [PubMed]

29. Margulis, L. Symbiogenesis and symbionticism. In Symbiosis as a Source of Evolutionary Innovation: Speciation and Morphogenesis; Margulis, L., Fester, R., Eds.; MIT Press: Cambridge, MA, USA, 2001; pp. 1-14, ISBN 9780262519908.

30. Reveillaud, J.; Maignien, L.; Eren, M.A.; Huber, J.A.; Apprill, A.; Sogin, M.L.; Vanreusel, A. Host-specificity among abundant and rare taxa in the sponge microbiome. ISME J. 2014, 8, 1198-1209. [CrossRef] [PubMed]

31. Schmitt, S.; Tsai, P.; Bell, J.; Fromont, J.; Ilan, M.; Lindquist, N.; Perez, T.; Rodrigo, A.; Schupp, P.J.; Vacelet, J.; et al. Assessing the complex sponge microbiota: Core, variable and species-specific bacterial communities in marine sponges. ISME J. 2012, 6, 564-576. [CrossRef] [PubMed]

32. Lee, H.S.; Kwon, K.K.; Kang, S.G.; Cha, S.S.; Kim, S.J.; Lee, J.H. Approaches for novel enzyme discovery from marine environments. Curr. Opin. Biotechnol. 2010, 21, 353-357. [CrossRef] [PubMed]

33. Newman, D.J. Predominately uncultured microbes as sources of bioactive agents. Front. Microbiol. 2016, 7, 1-15. [CrossRef] [PubMed]

34. Macintyre, L.; Zhang, T.; Viegelmann, C.; Martinez, I.J.; Cheng, C.; Dowdells, C.; Abdelmohsen, U.R.; Gernert, C.; Hentschel, U.; Edrada-Ebel, R.A. Metabolomic tools for secondary metabolite discovery from marine microbial symbionts. Mar. Drugs 2014, 12, 3416-3448. [CrossRef] [PubMed]

35. Egan, S.; Thomas, T.; Kjelleberg, S. Unlocking the diversity and biotechnological potential of marine surface associated microbial communities. Curr. Opin. Microbiol. 2008, 11, 219-225. [CrossRef] [PubMed]

36. Abdelmohsen, U.R.; Bayer, K.; Hentschel, U. Diversity, abundance and natural products of marine sponge-associated actinomycetes. Nat. Prod. Rep. 2014, 31, 381. [CrossRef] [PubMed]

37. Fenical, W. Marine pharmaceuticals. Oceanography 2006, 19, 110-119. [CrossRef]

38. Bull, A.T.; Stach, J.E.M. Marine actinobacteria: New opportunities for natural product search and discovery. Trends Microbiol. 2007, 15, 491-499. [CrossRef] [PubMed]

39. Wang, G. Diversity and biotechnological potential of the sponge-associated microbial consortia. J. Ind. Microbiol. Biotechnol. 2006, 33, 545-551. [CrossRef] [PubMed]

40. Barde, S.R.; Sakhare, R.S.; Kanthale, S.B.; Chandak, P.G.; Jamkhande, P.G. Marine bioactive agents: A short review on new marine antidiabetic compounds. Asian Pacific J. Trop. Dis. 2015, 5, 209-213. [CrossRef]

41. World Health Organisation. The Top 10 Causes of Death. Available online: http://www.who.int/ mediacentre/factsheets/fs310/en/ (accessed on 22 August 2017).

42. Lauritano, C.; Ianora, A. Marine organisms with anti-diabetes properties. Mar. Drugs 2016, 14, 220. [CrossRef] [PubMed]

43. Pandey, S.; Sree, A.; Dash, S.S.; Sethi, D.P.; Chowdhury, L. Diversity of marine bacteria producing beta-glucosidase inhibitors. Microb. Cell. Fact. 2013, 12, 35. [CrossRef] [PubMed] 
44. Pandey, S.; Sree, A.; Dash, S.S.; Sethi, D.P. A novel method for screening beta-glucosidase inhibitors. BMC Microbiol. 2013, 13, 55. [CrossRef] [PubMed]

45. Schmidt, D.D.; Frommer, W.; Müller, L.; Truscheit, E. Glucosidase inhibitoren aus Bazillen. Naturwissenschaften 1979, 66, 584-585. [CrossRef] [PubMed]

46. Asano, N. Glycosidase inhibitors: Update and perspectives on practical use. Glycobiology 2003, 13, 93-104. [CrossRef] [PubMed]

47. Niwa, T.; Inouye, S.; Tsuruoka, T.; Koaze, Y.; Niida, T. “Nojirimycin” as a potent inhibitor of glucosidase. Agric. Biol. Chem. 1970, 34, 966-968. [CrossRef]

48. Rath, C.M.; Janto, B.; Earl, J.; Ahmed, A.; Hu, F.Z.; Hiller, L.; Dahlgren, M.; Kreft, R.; Yu, F.; Wolff, J.J.; et al. Meta-omic characterization of the marine invertebrate microbial consortium that produces the chemotherapeutic natural product ET-743. ACS Chem. Biol. 2011, 6, 1244-1256. [CrossRef] [PubMed]

49. Esposito, G.; Teta, R.; Miceli, R.; Ceccarelli, L.S.; Della Sala, G.; Camerlingo, R.; Irollo, E.; Mangoni, A.; Pirozzi, G.; Costantino, V. Isolation and assessment of the in vitro anti-tumor activity of Smenothiazole A and B, chlorinated thiazole-containing peptide/polyketides from the Caribbean sponge, Smenospongia aurea. Mar. Drugs 2015, 13, 444-459. [CrossRef] [PubMed]

50. Teta, R.; Irollo, E.; Della Sala, G.; Pirozzi, G.; Mangoni, A.; Costantino, V. Smenamides A and B, chlorinated peptide/polyketide hybrids containing a dolapyrrolidinone unit from the Caribbean sponge Smenospongia aurea. Evaluation of their role as leads in antitumor drug research. Mar. Drugs 2013, 11, 4451-4463. [CrossRef] [PubMed]

51. Rao, K.V.; Santarsiero, B.D.; Mesecar, A.D.; Schinazi, R.F.; Tekwani, B.L.; Hamann, M.T. New Manzamine alkaloids with activity against infectious and tropical parasitic diseases from an indonesian sponge. J. Nat. Prod. 2003, 66, 823-828. [CrossRef] [PubMed]

52. Kobayashi, J.; Tsuda, M. Structures and biogenesis of Manzamines and related alkaloids. Heterocycles 1997, 46, 765-794. [CrossRef]

53. Magnier, E.; Langlois, Y. Manzamine alkaloids, syntheses and synthetic approaches. Tetrahedron 1998, 54, 6201-6258. [CrossRef]

54. Yousaf, M.; El Sayed, K.A.; Rao, K.V.; Lim, C.W.; Hu, J.F.; Kelly, M.; Franzblau, S.G.; Zhang, F.; Peraud, O.; Hill, R.T.; et al. 12,34-Oxamanzamines, novel biocatalytic and natural products from manzamine producing Indo-Pacific sponges. Tetrahedron 2002, 58, 7397-7402. [CrossRef]

55. Palomo, S.; González, I.; De La Cruz, M.; Martín, J.; Tormo, J.R.; Anderson, M.; Hill, R.T.; Vicente, F.; Reyes, F.; Genilloud, O. Sponge-derived Kocuria and Micrococcus spp. as sources of the new thiazolyl peptide antibiotic Kocurin. Mar. Drugs 2013, 11, 1071-1086. [CrossRef] [PubMed]

56. Montalvo, N.F.; Mohamed, N.M.; Enticknap, J.J.; Hill, R.T. Novel actinobacteria from marine sponges. Antonie Van Leeuwenhoek 2005, 87, 29-36. [CrossRef] [PubMed]

57. Zheng, L.; Chen, H.; Han, X.; Lin, W.; Yan, X. Antimicrobial screening and active compound isolation from marine bacterium NJ6-3-1 associated with the sponge Hymeniacidon perleve. World J. Microbiol. Biotechnol. 2005, 21, 201-206. [CrossRef]

58. Pabel, C.T.; Vater, J.; Wilde, C.; Franke, P.; Hofemeister, J.; Adler, B.; Bringmann, G.; Hacker, J.; Hentschel, U. Antimicrobial activities and matrix-assisted laser desorption/ionization mass spectrometry of Bacillus isolates from the marine sponge Aplysina aerophoba. Mar. Biotechnol. 2003, 5, 424-434. [CrossRef] [PubMed]

59. Liu, Q.A.; Shao, C.L.; Gu, Y.C.; Blum, M.; Gan, L.S.; Wang, K.L.; Chen, M.; Wang, C.Y. Antifouling and fungicidal resorcylic acid lactones from the sea anemone-derived fungus Cochliobolus lunatus. J. Agric. Food Chem. 2014, 62, 3183-3191. [CrossRef] [PubMed]

60. ChemSpider ID 58738. Nojirimycin. Available online: http:/ / www.chemspider.com/Chemical-Structure. 58738.html?rid=8ee6c8fc-333c-4358-896f-d569bf9c95a9\&page_num=0 (accessed on 17 October 2017).

61. ChemSpider ID 97236. Trabectedin. Available online: http:/ /www.chemspider.com/Chemical-Structure. 97236.html?rid=41381930-9347-4a57-a7e8-32fbbe0a8256 (accessed on 17 October 2017).

62. Schöffski, P.; Dumez, H.; Wolter, P.; Stefan, C.; Wozniak, A.; Jimeno, J.; Van Oosterom, A.T. Clinical impact of trabectedin (ecteinascidin-743) in advanced/metastatic soft tissue sarcoma. Expert Opin. Pharmacother. 2008, 9, 1609-1618. [CrossRef] [PubMed]

63. Janssen Products Ltd. Yondelis ${ }^{\circledR}$. Available online: https://www.yondelis.com/ (accessed on 21 August 2017). 
64. ChemSpider ID 35516725. Smenothiazole A. Available online: http://www.chemspider.com/ChemicalStructure.35516725.html?rid=5c041417-c159-4802-bfad-31e03bd22214 (accessed on 17 October 2017).

65. ChemSpider ID 35516726. Smenothiazole B. Available online: http://www.chemspider.com/ChemicalStructure.35516726.html?rid=b3eaff42-e7ed-4f12-9568-64fa222c485c (accessed on 17 October 2017).

66. Sakai, R.; Higa, T.; Jefford, C.W.; Bernardinelli, G. Manzamine A, a novel antitumor alkaloid from a sponge. J. Am. Chem. Soc. 1986, 108, 6404-6405. [CrossRef]

67. ChemSpider ID 5006904. Manzamine A. Available online: http://www.chemspider.com/ChemicalStructure.5006904.html?rid=bc7b7a2e-93b4-4408-a08f-0d78ec044124 (accessed on 17 October 2017).

68. ChemSpider ID 29215512. Kocurin. Available online: http:/ /www.chemspider.com/Chemical-Structure. 29215512.html?rid=29adbdad-a08f-4d47-a6de-0a9c86532abd\&page_num=0 (accessed on 17 October 2017).

69. ChemSpider ID 58486. Norharman. Available online: http:/ / www.chemspider.com/Chemical-Structure. 58486.html?rid=2d9b1de5-41ec-43d4-9220-f2fad643b678 (accessed on 17 October 2017).

70. ChemSpider ID 24672437. Zeaenol. Available online: http:/ /www.chemspider.com/Chemical-Structure. 24672437.html?rid=822b22bb-71c1-4292-afe1-85c89ddc4e3b\&page_num=0 (accessed on 17 October 2017).

71. Munro, M.H.G.; Blunt, J.W.; Dumdei, E.J.; Hickford, S.J.H.; Lill, R.E.; Li, S.; Battershill, C.N.; Duckworth, A.R. The discovery and development of marine compounds with pharmaceutical potential. Prog. Ind. Microbiol. 1999, 35, 15-25. [CrossRef]

72. Kijjoa, A.; Sawangwong, P. Drugs and cosmetics from the sea. Mar. Drugs 2004, 2, 73-82. [CrossRef]

73. Sagar, S.; Kaur, M.; Minneman, K.P. Antiviral lead compounds from marine sponges. Mar. Drugs 2010, 8 , 2619-2638. [CrossRef] [PubMed]

74. Bergmann, W.; Feeney, R.J. The isolation of a new thymine pentoside from sponges. J. Am. Chem. Soc. 1950, 72, 2809-2810. [CrossRef]

75. Essai Inc. Halaven ${ }^{\circledR}$. Available online: http://www.halaven.com/metastatic-breast-cancer (accessed on 21 August 2017).

76. Hirata, Y.; Ljemura, D. Halichondrins-antitumor polyether Macrolides from a marine sponge. Pure Appl. Chem. 1986, 58, 701-710. [CrossRef]

77. Menis, J.; Twelves, C. Eribulin (Halaven): A new, effective treatment for women with heavily pretreated metastatic breast cancer. Breast Cancer Targets Ther. 2011, 3, 101-111. [CrossRef] [PubMed]

78. Seattle Genetics Inc. ADCETRIS ${ }^{\circledR}$. Available online: http://www.seattlegenetics.com/products/adcetris-us (accessed on 21 August 2017).

79. Pettit, G.R.; Kamano, Y.; Herald, C.L.; Tuinman, A.A.; Boettner, F.E.; Kizu, H.; Schmidt, J.M.; Baczynskyj, L.; Tomer, K.B.; Bontems, R.J. The isolation and structure of a remarkable marine animal antineoplastic constituent: Dolastatin 10. J. Am. Chem. Soc. 1987, 109, 6883-6885. [CrossRef]

80. Katz, J.; Janik, J.E.; Younes, A. Brentuximab Vedotin (SGN-35). Clin. Cancer Res. 2011, 17, $6428-6436$. [CrossRef] [PubMed]

81. Rinehart, K.L. Antitumor compounds from tunicates. Med. Res. Rev. 2000, 20, 1-27. [CrossRef]

82. Corey, E.J.; Gin, D.Y.; Kania, R.S. Enantioselective total synthesis of Ecteinascidin 743. J. Am. Chem. Soc. 1996, 118, 9202-9203. [CrossRef]

83. Moss, C.; Green, D.H.; Perez, B.; Velasco, A.; Henriquez, R.; McKenzie, J.D. Intracellular bacteria associated with the ascidian Ecteinascidia turbinata: Phylogenetic and in situ hybridisation analysis. Mar. Biol. 2003, 143, 99-110. [CrossRef]

84. Pérez-Matos, A.E.; Rosado, W.; Govind, N.S. Bacterial diversity associated with the Caribbean tunicate Ecteinascidia turbinata. Antonie van Leeuwenhoek 2007, 92, 155-164. [CrossRef] [PubMed]

85. Penesyan, A.; Kjelleberg, S.; Egan, S. Development of novel drugs from marine surface associated microorganisms. Mar. Drugs 2010, 8, 438-459. [CrossRef] [PubMed]

86. Bhatnagar, I.; Kim, S.K. Immense essence of excellence: Marine microbial bioactive compounds. Mar. Drugs 2010, 8, 2673-2701. [CrossRef] [PubMed]

87. Kumar Jha, R.; Zi-Rong, X. Biomedical compounds from marine organisms. Mar. Drugs 2004, 2, $123-146$. [CrossRef]

88. Edrada, R.A.; Proksch, P.; Wray, V.; Witte, L.; Müller, W.E.G.; van Soest, R.W.M. Four new bioactive Manzamine-type alkaloids from the Philippine marine sponge Xestospongia ashmorica. J. Nat. Prod. 1996, 59, 1056-1060. [CrossRef] [PubMed] 
89. Nakamura, H.; Deng, S.; Kobayashi, J.; Ohizumi, Y.; Tomotake, Y.; Matsuzaki, T.; Hirata, Y. Keramamine-A and -B, novel antimicrobial alkaloids from the Okinawan marine sponge Pellina sp. Tetrahedron Lett. 1987, 28, 621-624. [CrossRef]

90. Ang, K.K.H.; Holmes, M.J.; Higa, T.; Hamann, M.T.; Kara, U.A.K. In vivo antimalarial activity of the $\beta$-carboline alkaloid Manzamine A. Antimicrob. Agents Chemother. 2000, 44, 1645-1649. [CrossRef] [PubMed]

91. El Sayed, K.A.; Kelly, M.; Kara, U.A.K.; Ang, K.K.H.; Katsuyama, I.; Dunbar, D.C.; Khan, A.A.; Hamann, M.T. New manzamine alkaloids with potent activity against infectious diseases. J. Am. Chem. Soc. 2001, 123, 1804-1808. [CrossRef] [PubMed]

92. World Health Organization. Global TB Report 2016 Facts. Available online: http://www.who.int/tb/ publications / factsheet_global.pdf?ua=1 (accessed on 22 August 2017).

93. Rojas, J.L.; Martín, J.; Tormo, J.R.; Vicente, F.; Brunati, M.; Ciciliato, I.; Losi, D.; Van Trappen, S.; Mergaert, J.; Swings, J.; et al. Bacterial diversity from benthic mats of Antarctic lakes as a source of new bioactive metabolites. Mar. Genomics 2009, 2, 33-41. [CrossRef] [PubMed]

94. Sharma, G.M.; Burkholder, P.R. Studies on antimicrobial substances of sponges. Isolation, purification, and properties of a new bromine-containing antibacterial substance. J. Antibiot. (Tokyo) 1967, 20, 200-203. [PubMed]

95. Zhang, H.; Zhao, Z.; Wang, H. Cytotoxic natural products from marine sponge-derived microorganisms. Mar. Drugs 2017, 15, 68. [CrossRef] [PubMed]

96. Abad, M.J.; Bedoya, L.M.; Bermejo, P. Marine compounds and their antimicrobial activities. In Science against Microbial Pathogens: Communicating Current Research and Technological Advances; Mendez-Vilas, A., Ed.; Formatex Research Center: Badajoz, Spain, 2011; pp. 1293-1306, ISBN 978-84-939843-2-8.

97. Indraningrat, A.A.G.; Smidt, H.; Sipkema, D. Bioprospecting sponge-associated microbes for antimicrobial compounds. Mar. Drugs 2016, 14, 87. [CrossRef] [PubMed]

98. Ahmed, S.; Canal, S. Review of natural products from marine organisms in the Red Sea. Int. J. Pharm. Sci. Res. 2017, 8, 940-974. [CrossRef]

99. Gomes, N.G.M.; Dasari, R.; Chandra, S.; Kiss, R.; Kornienko, A. Marine invertebrate metabolites with anticancer activities: Solutions to the "supply problem". Mar. Drugs 2016, 14. [CrossRef] [PubMed]

100. Daletos, G.; Ancheeva, E.; Chaidir, C.; Kalscheuer, R.; Proksch, P. Antimycobacterial metabolites from marine invertebrates. Arch. Pharm. (Weinheim) 2016, 349, 763-773. [CrossRef] [PubMed]

101. Cheung, R.C.F.; Ng, T.B.; Wong, J.H.; Chen, Y.; Chan, W.Y. Marine natural products with anti-inflammatory activity. Appl. Microbiol. Biotechnol. 2016, 100, 1645-1666. [CrossRef] [PubMed]

102. Pimentel-Elardo, S.M.; Kozytska, S.; Bugni, T.S.; Ireland, C.M.; Moll, H.; Hentschel, U. Anti-parasitic compounds from Streptomyces sp. strains isolated from Mediterranean sponges. Mar. Drugs 2010, 8, 373-380. [CrossRef] [PubMed]

103. Garcia, M.; Monzote, L. Marine products with anti-protozoal activity: A review. Curr. Clin. Pharmacol. 2014, 9, 258-270. [CrossRef] [PubMed]

104. Watts, K.R.; Tenney, K.; Crews, P. The structural diversity and promise of antiparasitic marine invertebrate-derived small molecules. Curr. Opin. Biotechnol. 2011, 21, 808-818. [CrossRef] [PubMed]

105. Tullius Scotti, M.; Scotti, L.; Ishiki, H.; Fávaro Ribeiro, F.; Marques Duarte da Cruz, R.; Pedrosa de Oliveira, M.; Jaime Bezerra Mendonça, F. Natural products as a source for antileishmanial and antitrypanosomal agents. Comb. Chem. High. Throughput Screen. 2016, 19, 537-553. [CrossRef]

106. Brinkmann, C.; Marker, A.; Kurtböke, D. An overview on marine sponge-symbiotic bacteria as unexhausted sources for natural product discovery. Diversity 2017, 9, 40. [CrossRef]

107. Epstein, S. The phenomenon of microbial uncultivability. Curr. Opin. Microbiol. 2013, 16, 636-642. [CrossRef] [PubMed]

108. Leal, M.C.; Calado, R. Marine natural products: Biodiscovery, biodiversity, and bioproduction. In Bioactive Natural Products: Chemistry and Biology; Brahmachari, G., Ed.; Wiley: Hoboken, NJ, USA, 2015; pp. 473-490, ISBN 9783527684403.

109. Leal, M.; Sheridan, C.; Osinga, R.; Dionísio, G.; Rocha, R.; Silva, B.; Rosa, R.; Calado, R. Marine microorganism-invertebrate assemblages: Perspectives to solve the "supply problem" in the initial steps of drug discovery. Mar. Drugs 2014, 12, 3929-3952. [CrossRef] [PubMed]

110. Sweet, M.J.; Bulling, M.T. On the importance of the microbiome and pathobiome in coral health and disease. Front. Mar. Sci. 2017, 4, 9. [CrossRef] 
111. Sweet, M.J.; Smith, D.; Bythell, J.C.; Craggs, J. Changes in microbial diversity associated with two coral species recovering from a stressed state in a public aquarium system. J. Zoo Aquarium Res. 2013, 1, 52-60.

112. MaCuMBA Group. MaCuMBA Project Legacy Brochure. Available online: http:/ /www.macumbaproject. eu/images/MACUMBA/Media/Public_Deliverables/Legacy_Brochure_FINAL_HR.pdf (accessed on 23 August 2017).

113. Trindade, M.; van Zyl, L.J.; Navarro-Fernández, J.; Elrazak, A.A. Targeted metagenomics as a tool to tap into marine natural product diversity for the discovery and production of drug candidates. Front. Microbiol. 2015, 6. [CrossRef] [PubMed] article distributed under the terms and conditions of the Creative Commons Attribution (CC BY) license (http://creativecommons.org/licenses/by/4.0/). 